\title{
Punishment, Socially Deprived Offenders, and Democratic Community
}

\author{
Jeffrey Howard
}

\begin{abstract}
The idea that victims of distributive injustice who commit crimes ought not to be subject to punishment has attracted serious attention in recent legal and political philosophy. R. A. Duff has argued, for example, that states that perpetrate distributive injustice lack the moral standing to punish victims of such injustice who commit crimes. A crucial premise in his argument concerns the fact that when courts in liberal society mete out legitimate criminal punishments, they are conceived as acting in the name of all citizens - on behalf of the whole political community. Resisting this premise, Peter Chau has suggested that courts ought to be conceived as acting only in the name of "just citizens": citizens who cannot be plausibly seen as having contributed to distributive injustice. When conceived in this way, Chau argues, courts can no longer plausibly be regarded as lacking standing to punish.

This article uses the debate between Duff and Chau to explain why the question of whether to punish socially deprived offenders can only be answered adequately when connected to broader concerns of democratic theory. Specifically, it argues that Chau's proposal is not available within the context of the kind of political community upon which (Duff rightly believes) a system of liberal criminal law depends for its justification and maintenance: a community in which citizens see the law as embodying shared norms whose specific demands they disagree about. State officials are morally permitted to see themselves as acting on behalf of a subset of the citizenry, I argue, only in circumstances of democratic crisis: circumstances in which a moral community can no longer be plausibly said to exist. In the normal preponderance of cases, the authority to punish is therefore compromised. Nevertheless, I argue, to have one's authority compromised is not to forfeit it entirely. So long as sufficient activity is afoot in an unjust state to re-orient it toward justice, the authority to punish plausibly remains intact.
\end{abstract}

\section{Introduction}

Do courts have the right to punish victims of social injustice who commit crimes? This question has attracted significant recent attention in political and legal philosophy. R.A. Duff has argued that states that perpetrate distributive injustice lack the moral standing to punish victims of such injustice who commit crimes (1998, 2000, 2001, pp. 179-201; 2007, pp. 191-194; 2010). By treating such citizens as less than full members of the political community, it has compromised its authority to hold them accountable as full members. A crucial premise in Duff's argument concerns the fact that when courts in a liberal society issue punishments for the contravention of legitimate criminal laws, they are conceived as acting in the name of all citizens - on behalf of the whole political community. Resisting this premiss, Peter Chau has recently suggested that courts in liberal society ought to be conceived as acting only in the name of "just citizens": those citizens who, because of their voting, advocacy, or 
other distributive justice-promoting political activism, cannot be seen as having wronged the victims of distributive injustice (2012). When we conceive of courts in this way, Chau argues, it is no longer plausible to think that they lack the right to punish.

From the perspective of a judge or a prosecutor contemplating whether to try or prosecute a particular case in which the criminal defendant is a victim of distributive injustice, Chau's suggestion is intriguing. It would allow such a morally motivated state official to say to herself: Were I speaking on behalf of the whole community - the community whose majority has wronged this defendant by flouting the fundamental moral values that bind us all together - then I would lack the moral right to call this defendant to answer for her affront to those very values. But if I conceive myself only as speaking on behalf of the portion of the community that has not so acted - the portion who has, in some way, opposed the injustices that condemn this potential offender to a life of social deprivation - then my right to call her to answer remains intact. With such an account in hand, citizens and officials can rest assured that punishing victims of distributive injustice who commit crimes is morally unproblematic, after all - so long as there is somebody around who can be seen as opposing the injustices.

I believe that Chau's proposal has plausibility only when it is viewed independently of broader concerns in political philosophy. The idea that state officials should see themselves as acting only in the name of a subset of the citizenry, I argue, is incompatible with the demands of legitimacy in a genuine democracy. My aim in this essay is to explain why. Because Chau's proposal is directed at Duff, my strategy will be to explain why such a proposal defies the vision of political community upon which Duff's own account of legitimate punishment explicitly (and rightly) depends. By refining Duff's vision of political community in a Rawlsian direction so that it is conceived as a vision of democratic community - of citizens united around a common procedure for provisionally settling reasonable disagreements about the implications of their shared values - I shall argue that citizens and officials have strong moral reason to regard all laws and policies within such a community as authorized and enforced in the name of all. Moreover, these reasons sometimes obtain even when the legislation in question is beyond the pale of reasonable disagreement - when it clearly betrays the community's defining values - so long as that legislation plausibly represents a rectifiable disalignment among citizens about the demands of the convictions they share. Only when such legislation represents a stable fracture does it become morally permissible for state officials to conceive themselves as 
democratically disassociated from their co-citizens. For, in such circumstances, moral community no longer obtains. Only under such dire circumstances, I contend, does Chau's proposal become applicable.

In Part I, I provide some unscientific empirical background to motivate the political significance of the philosophical discussion. In Part II, I shall modify Duff's vision of political community to incorporate the fact of reasonable disagreement among citizens about the implications of their shared convictions, which paves the path toward conceiving his view as one of democratic community. I argue that so long as a policy is subject to reasonable disagreement, officials properly view themselves as enacting and enforcing it on behalf of all in the political community, even if they or other citizens disagree about its justice. I also argue that, in order to be a political community, citizens must have a roughly shared account of the kinds of laws that would constitute flagrant violations of their shared values - that would lie beyond the pale of reasonable disagreement.

In Part III, I evaluate how to think about the legitimacy of punishing "socially deprived" offenders within this democratic framework. I argue that the answer to this question hinges on what we take the exact policy regime that perpetrates "distributive injustice" to be, and whether the assertion of its injustice is subject to reasonable disagreement. If it is, then it is not plausible to think that the state has flouted its values, and thus forfeited its standing to punish, by enacting that policy regime. Fittingly, in such a case, it would not be plausible for those on one side of the reasonable disagreement to think that their moral community has been fractured, thus opening the possibility for legal enactments not to be conceived as made in the name of all. However, if the policy regime is judged to be beyond the pale of what any reasonable liberal political conception of justice would allow, the analysis becomes more complicated.

In Part IV, I review Duff's argument that distributively unjust states lose the standing to punish, and I examine and refine Chau's response to the argument: that courts can see themselves as acting on behalf of only just citizens when they punish socially deprived offenders. Then, in Part V, I situate their dispute in the context of the wider discussion by examining how political officials and just citizens should see their relation to the rest of the polity in the face of persistent and egregiously unjust legislation, such as the sort of distributive injustice Duff has in mind. In these circumstances, I believe 
it is a precarious matter of political judgement whether the unjust legislation in question is evidence of a stable fracture in the moral consciousness of the society, or a rectifiable disalignment between citizens that could realistically be repaired. If the latter, political officials have strong moral reason not to see themselves as representing only the just citizens when they enforce just statutes (such as murder or assault prohibitions); they do not yet have reason to see themselves as morally divorced from their fellow citizens. However, if the disagreement is evidence of a fundamental impasse within the political community about the deep demands of justice, then officials have reason to "go rogue" - to see themselves as only representing (whom they properly regard as) the just citizens, even as they are officially tasked with representing the whole community. Nevertheless, I argue that there is strong moral presumption, in cases of uncertainty, to assume that the injustice in question is a temporary disalignment, not a permanent fracture. In such circumstances, judges should see themselves as acting in the name of the whole citizenry.

Finally, in Part VI, I remark on the implications of the argument for the actual practice of punishment, contending that they are not as puzzling as they may first appear. That judges should normally think of themselves as acting on behalf of the whole citizenry suggests that they should take their standing to punish to be compromised with respect to offenders who are victims of egregious social injustice. But to have one's standing morally compromised is not to lose it entirely. So long as sufficient activity is afoot in an unjust state to re-orient it toward justice, I argue, the authority to punish remains intact.

\section{Setting the Stage: Political Context ${ }^{1}$}

The ghettos of Baltimore, Birmingham, Cleveland, Detroit, Los Angeles, Newark, New Orleans, New York, Philadelphia, St. Louis, and Washington, DC - to name a few - constitute ground zero of urban poverty in the United States of America. What happens in these ghettos (as anywhere) is generated by a complex policy regime - a vast array of statutes and national and local policies concerning taxation, welfare programmes, education, healthcare policy, gun policy, employment law, and drug policy alongside the countless individual choices made in the contexts forged by those policies.

As William Julius Wilson has famously explored, a principal problem faced by the urban underclass is that its members are subject to considerable social exclusion and alienation from mainstream society

\footnotetext{
${ }^{1}$ NOTE: This section is not strictly necessary to the philosophical discussion. I therefore invite the Selection Committee member reviewing this essay to skip that section if (s)he is concerned about length.
} 
(Wilson 1987: pp. 7-8). Yet while white flight and the more recent exodus of middle-class AfricanAmericans from these communities certainly succeeded in accomplishing a physical segregation, it is nevertheless striking just how close these communities are to more affluent ones. Take two sister neighbourhoods in New York, each with just less than 700,000 residents. The South Bronx is the home to America's poorest congressional district (New York's $16^{\text {th }}$ )—with $42 \%$ of its residents below the poverty line, and about half of its children living in poverty. Yet only three-quarters of a mile away resides one of America's richest congressional districts (New York's 14 ${ }^{\text {th }}$ ), which includes most of Manhattan's East Side and several other neighbourhoods. The juxtaposition, at less than a $\$ 3$ subway between the two, makes the inequality hard to ignore. While one of the favoured complaints of NY-14 citizens in the last year to the city were dead trees, the preoccupation in NY-16 tended to be more focused on crucial infrastructure: 45,748 complaints of broken heating, compared to 7,963 in NY-14, and 22,464 complaints of broken plumbing, compared to 2,913. It is no small wonder that a community with one Starbucks - compared to the ninety of NY-14 - has bigger fish to fry. $39 \%$ of children in NY16 have children, despite a significantly lower marital rate; $22.6 \%$ of households in NY-16 have single mothers, compared to $2.6 \%$ in NY-14. Almost 84,000 of its less than 700,000 residents receive food stamps. Only $9 \%$ of NY-14's residents failed to graduate high school. In, NY-16 41\% are high school drop-outs, and a further $28 \%$ received no further education after high school. ${ }^{2}$

As Elijah Anderson notes, such relative social deprivation is reinforced by, and exacerbates, the most urgent problem facing these communities: criminal violence.

\begin{abstract}
The inclination to violence springs from the circumstances of life among the ghetto poor - the lack of jobs that pay a living wage, limited basic public services (police response in emergencies, building maintenance, trash pickup, lighting...the stigma of race, the fallout from rampant drug use and drug trafficking, and the resulting alienation and absence of hope for the future. Simply living in such an environment places young people at special risk of falling victim to aggressive behavior. Although there are often forces in the community that can counteract the negative influences - by far the most powerful is a strong, loving, 'decent' (as inner-city residents put it) family that is committed to middle-class values - the despair is pervasive enough to have spawned an oppositional culture, that of 'the street,' whose norms are often consciously opposed to those of mainstream society (Anderson 1999: p. $32)$.
\end{abstract}

The murder rate in NY-16 is four times higher than the murder rate in NY-14; the former had 88 murders in 2010 (nearly 900 in total for New York City that year ${ }^{3}$ ). This trend of violence extends far outside the South Bronx, across most of urban, poor America. Last year, homicide in New Orleans was

2 “The Wealth Gap is .75 Miles Wide," in New York Magazine, 3 July 2011. Available at http://nymag.com/news/features/wealth-gap-2011-7/index1.html

3 http://www.disastercenter.com/crime/nycrime.htm 
declared a public health emergency. In a public statement, the mayor accurately reported that a student attending one tough-area high school "was more likely to be killed than a soldier in Afghanistan."4

A considerable portion of crime surrounds the illegal narcotics trade. In NY-14, there were 2,481 charges of marijuana possession in 2010. In NY-16, there were 11,001. But marijuana - despite its preposterous classification as a Schedule I drug under the U.S. Code ("high potential for abuse") alongside heroin - is hardly the central issue. Drug dealing constitutes one of the most lucrative forms of business among an otherwise economically despondent population. Because the drugs are illegal, their distribution and sale engender all the familiar and destructive effects of black markets: disagreements are resolved not through lawsuits, but through violence, and thus players have an economic interest in establishing a reputation as credible and effective in following through on violent threats (Miron 2001: p. 615). Repeated iterations of this game engender predictability but not peace. Violence begets violence, as different gangs with different territories retaliate with increasing brutality for strikes against them, their targets respond, and so on. As the war escalates, the surrounding community deteriorates.

Police policy attempts to stop the drug war. But such attempts exacerbate perceptions of racism; the notorious disparity in sentencing for different forms of cocaine has long been the source of criticism. Significantly lighter U.S. federal penalties obtain for powder cocaine - used predominantly by whites than for crack cocaine - used predominantly by blacks. The sole difference is that the latter is mixed with baking soda and cooked, yet the penalties for the latter have tended to be roughly 100 times harsher (Butler 2004: p. 988). (Since 2010, due to an Obama administration-led effort, sentences for crack cocaine are now only 18 times harsher. ${ }^{5}$ ) The overtly racial element to the drug controversy manifests in a significant number of arrests each year for nonviolent drug offenses; 1.5 million Americans are arrested each year for drug offenses. One million are tossed in jail each year. The racial effect becomes apparent; one in five black American men will spend some of their life in prison. ${ }^{6}$

4 http://www.nytimes.com/2011/12/08/us/new-orleans-struggles-to-stem-homicides.html?pagewanted=all The problems of New Orleans are particularly worrisome; there are few major gangs and no major drug war, ruling out two factors that contribute to crime in many other poor contexts.

5 http://www.aclu.org/drug-law-reform-racial-justice/president-obama-poised-sign-bill-reducing-cocaine-sentencingdisparit

6 http://www.economist.com/node/13237193 
Importantly, the crackdown on drugs in urban ghettos does not eliminate their prevalence. They remain, and the gangs that run their provision do, too. As the creators of the acclaimed television program The Wire note:

\begin{abstract}
...the dealers and fiends win because they are legion. They've won because...the federal government have imprisoned thousands and arrested tens of thousands and put maybe a hundred thousand on the parole and probation rolls - and still it isn't close to enough. By raw demographics, the men and women of the corners can claim victory. In Baltimore alone- a city of fewer than seven hundred thousand souls, with some of the highest recorded rates of intravenous drug use in the nation - they are fifty, perhaps even sixty thousand strong - three of them for every available prison bed in the entire state of Maryland. The slingers are manning more than a hundred open-air corners, serving up product as fat as they can get if off a southbend Metroliner. And the fiends are chasing down that blast twenty-four, seven. In neighborhoods where no other wealth exists, they have constructed an economic engine so powerful that they'll readily sacrifice everything to it. And make no mistake, that engine is humming. No slacking profit margins, no recessions, no bad quarterly reports, no layoffs, no naturalized unemployment rate. In the empty heart of our cities, the culture of drugs has created a wealth-generating structure so elemental and enduring that it can legitimately be called a social compact (Simon and Burns 2009: 66).
\end{abstract}

How should liberal political philosophers think about the citizens of these communities who engage in criminal conduct? Because my aim here is only to focus our attention on the real-world contexts that render relevant the philosophical dispute to be explored - so as to clarify just how high the stakes are in what follows - I can only hazard a provisional and partial answer here. The answer takes its cue from John Rawls's account of stability. According to Rawls, a conception of justice is stable if a society enacted in accordance with it generates the conditions of its own support - that is, its own freely willed support, from citizens' sense of justice, as opposed to support from coercion and brute force (1999: pp. 437-439; 2001: pp. 184-202; 2005: pp. 140-144). The crucial test of whether a conception of justice will be stable, Rawls believes, is whether its demands are congruent with what is required for citizens to pursue their good. If a conception of justice is not congruent with citizens' own good, citizens will become alienated from their sense of justice, and they will not be able to support the conception of justice (Cf. Paul Weithmann 2011: p. 53).

Rawls's concern with stability flows from his conviction that the concept of justice is practical; its point is to serve a social role in furnishing a shared basis of public justification (1980: p. 517). Therefore, a conception of justice unable to serve such a role enduringly is defective and thus properly rejected. But we need not endorse this ambitious thesis - G. A. Cohen (2008), for example, did not - in order to retain an interest in the question: do members of our social order regard the laws as congruent with their good? This question is important strategically, for sure, but its significance is more fundamental. Insofar as liberal-egalitarian principles of justice just are those principles that are in the equal interest of every free individual, the observation that a large group of citizens take their good to 
be furthered best by breaking the law should startle us. Of course, it is possible that such citizens are being unreasonable; it is possible that such citizens who commit crimes in the ghettos I have described are merely assigning greater value to their lives than the lives of others (helping themselves to more than justice allows them, in cases of economic crime). But if they are not unreasonable - and if they also believe that the demands of the law rest in conflict with the achievement of certain fundamental human goods - their behaviour could well be evidence that the putatively liberal-egalitarian state is not liberal-egalitarian at all.

This fear is motivated by empirical observations about the functional role of gangs. Involvement in gangs, and participation in the typically drug-centric criminal operations that are economically lucrative in urban ghettos, facilitates members' achievement of generalized human goods that all people have reason to value: the goods of income, belonging, self-respect, and protection. From this perspective, quitting gangs and staying in school strike adolescents as decidedly prudentially irrational, given the fact that such decisions would force them to renounce many of the features of their life that their partially developed conceptions of the good direct them to value. For a young man who is a member of a gang to decide to give up the gang, renouncing his life of crime, is for him to forfeit his claim to the only decent life he knows. As Mark Warr notes:

\begin{abstract}
Among adolescents, for whom acceptance among peers is often a priceless commodity, and for whom ridicule is a familiar form of interchange, the mere risk of ridicule may be sufficient to provoke participation in behavior that is undeniably dangerous, illegal, and morally reprehensible. To risk ridicule is to risk expulsion from or abandonment by the group, or to place in danger's one's legitimate claim to be a member of the group. To lose the group is to lose the identity and sometimes the prestige that it creates, as well as the sense of belonging it affords (Warr 2002: $\mathrm{p}$. 46).
\end{abstract}

Unsurprisingly, the group norms that character urban gangs are anything but liberal. Gangs demand allegiance in exchange for the distribution of the goods they provide - allegiance not merely to its members, privileging them about others, but to participation in the norms that keep the organization powerful and active in the community (Anderson 2000: p. 9). While these norms often require wrongdoing, the costs of disobeying them are extremely high.

The suggestion I am developing is this: while it is too fast to conclude that members of these communities are justified in committing criminal behaviour (Cf. Sarah Buss 1997), it would be damning enough were we to establish that the aspirationally liberal-egalitarian state had generated conditions, owing to unjust policies, in which it was prudentially rational - in the pursuit of familiar 
human goods - to act contrary to the demands of freedom and equality. And if that is what has happened, we can feel the intuitive pull of the thesis that such a state has forfeited its right to punish. By treating citizens as unworthy of being treated according to the ideals of freedom and equality, it has no business calling them to account for their affronts to those same values. That is the intuition that lies behind the philosophical debate I shall now engage.

\section{Toward a Democratic Interpretation of Duff's Conception of Community}

R. A. Duff believes that the circumstances I have just described are the result of egregious social injustice. He also believes that the body of citizens - by perpetrating such injustice - has lost its moral standing to punish victims of such injustice who commit crimes. I will review his argument for this thesis in greater detail below. For now, I want to focus on a crucial background assumption of his view: that courts should see themselves as acting on behalf of the whole citizenry when they issue punishments. Deciding whether this is a plausible assumption - or, as Peter Chau claims, one that we can jettison - will depend on securing a better understanding of the broader political philosophy in which it is situated. Because I shall develop Duff's political philosophy in a way that captures what I take to be the truth about the fundamental nature of liberal democracy, the implications of what follows are not merely of exegetical value; rather, they point toward a fruitful way of understanding liberaldemocratic citizens' proper attitudes toward one another and the legislation enacted in their name. The point of this section is to show that a proper understanding of liberal political community is, at its core, a vision of citizens who see their officials as acting in their name even when the laws they enforce are regarded by those citizens as less than fully just. This will be key to demonstrating the general unavailability of Chau's proposal.

As background to his influential communicative theory of punishment, R.A. Duff has argued that political communities are properly conceived of as moral communities "whose members are bound together by a shared commitment to certain defining values and by mutual respect and concern in the light of those values" (Duff 2001, p. 46). While Duff endorses the label "communitarian", his view of community does not presuppose that members share a certain substantive conception of the good life. Rather, the values that members of Duff's political community share are familiar liberal political values, namely “autonomy, freedom, privacy, and pluralism” (Duff 2001, p. 75). 
Duff's account of political community serves, inter alia, to identify the source of the moral values in reference to which the criminal law in a particular society is crafted. Citizens are jointly committed to holding one another responsible in light of the norms they share, and indeed to punishing one anothera process by which apology and restoration are made possible - when the shared norms are flouted. Newcomers to political and legal theory can be expected to pose an objection to such a vision, however: namely, that total agreement on moral values in a given community is an illusory, because unrealisable, aspiration. But as Duff adamantly emphasises, this aspiration does not belong to his conception of political community:

[E]ven if we agree on the structural features of community (mutual regard and a commitment to shared intrinsic vales), we can disagree fiercely about just what those values are, about what that regard requires, about who should count as members of the community. Some such disagreements can render community impossible: we can no longer respect one another as being committed to the same goals and values. But not all such disagreements, even if profound, destroy community (Duff 2001, p. 43).

What it would mean for community to be "destroyed" will be relevant later on. For now, however, it is worth asking: what happens, on Duff's view, when there is such disagreement? How is it resolved? One possibility is that it is resolved through deliberation, as intense discussion narrows differences and facilitates consensus. However, Duff gives no indication he endorses that solution. Moreover, he would not be justified even if he were to endorse it. Disagreement about justice is often perfectly understandable disagreement, owing to the difficulty of the questions involved. It is, to use familiar Rawlsian terminology, reasonable disagreement. ${ }^{7}$ And while we can try to see if deliberation will narrow the divide - it is bound to do some work among open-minded, rational people committed to listening to one another - one's political theory must not depend on its potential to do this. It must have some account of what to do in the face of disagreement about justice.

This leads to a second approach to overcoming reasonable disagreements about justice: finding some procedure to make provisional decisions in the face of them. There is considerable reason to assume this kind of view is Duff's preferred strategy. He says that, in a political community, "there will be room for substantial disagreement even about the community's central and defining goods, so long as there is agreement on how such goods are to be dealt with" (Duff 2001, p. 69, italics added). Duff does not, however, provide a procedure of this kind. His theory suffers, in other words, from what might be

7 That people can reasonably disagree about the nature and meaning of a good life has been a liberal mantra for a long time. The idea here is that free exercise of practical reason can lead people to divergent conclusions on matters of great importance, owing to the difficulty of the questions involved. This concerns the much-discussed idea of 'the burdens of judgement'. See Rawls 2005, pp. 54-58. 
called a "decision deficit". What might it be?

To answer this question, we need a sharper sense of what "settling disagreement" is actually supposed to involve. As Jeremy Waldron has influentially argued, "the felt need among the members of a certain group for a common framework or decision or course of action on some matter, even in the face of disagreement what that framework, decision or action should be, are the circumstances of politics" (1999, p. 102). This idea - that those who disagree about political decisions nevertheless agree that some decision is required - is a familiar and important feature of political experience. However, while Waldron is surely right that "legislation deserves respect because of the achievement it represents in the circumstances of politics: action-in-concert in the face of disagreement", morally motivated citizens are unlikely to afford respect to any old piece of legislation that provisionally settles some disagreement about justice. Rather, they will afford respect only to what they regard as acceptable solutions to their disagreements. Imagine each citizen ranking all the possible policies on a given issue from best to worst, and then drawing a line somewhere down the list to separate the morally tolerable from the morally intolerable policy possibilities. The sentiment Waldron describes will properly obtain only if the policy provisionally selected by the democratic community is "above the line", so to speak. If it is below the line - if the policy selected is a member of a citizen's "black list" of morally intolerable policies - then the attitude Waldron describes would be manifestly inappropriate.

So the picture of the political community has been refined: citizens disagree reasonably about justice, yet they agree that some acceptable solution is required in the face of their disagreement. Just because citizens disagree about tax policy does not mean they believe that everyone's tax rate should be set at $0 \%$; reasonable disagreement about justice is, in this way, crucially disanalogous from reasonable disagreement about the good life. ${ }^{8}$ But what constitutes the list of "acceptable solutions"? The answer

8 We are reminded of a familiar objection here. If, as familiar from such liberal theorists as Rawls, the fact of reasonable disagreement about the good life indicates that political power ought not be justified with reference to a particular view of the good, why does the fact of reasonable disagreement about a justice claim not similarly disqualify it from usage on political justification? The answer can be straightforwardly explained by revisiting the starting question for reasoning about what the liberal state should do, a question from which Duff himself presumably begins: what principles for the general regulation of behaviour treat others as free and equal? Now we can reexamine each kind of reasonable disagreement in light of this question. Firstly, the fact of reasonable disagreement about the good life prepares us to realise that letting others live their lives freely, as the starting commitment of the liberal state avows, will result in enduring pluralism. There is no impetus in a liberal society to overcome disagreements about the good life in the political realm. But reasonable disagreements about justice involve competing attempts to answer the starting question of liberal politics - they concern disputes about the demands of a shared commitment. Citizens who reasonably disagree about tax policy and police policy cannot thus plausibly think that their disagreements commit them to give up on 
is already in hand: the list of solutions about which disagreement is reasonable, rather than unreasonable. Take the question of how to respond to religious minorities that seek exemptions from laws that burden their religious practices. I shall grant for the sake of our argument that there are, at least, two reasonable ways to respond to such minorities. The first is to explain that these laws cannot be squared with the ideal of equal treatment under law; they threaten to ossify inherited group identities and compartmentalise the legal system into different sets of rules for citizens of different religious and cultural convictions, a result that would rest fundamentally at odds with the most plausible vision of what workable liberal-democratic order demands (e.g. Barry 2001). A second reasonable response would concede that certain accommodations are actually demanded by a genuine commitment to liberty of conscience, and that citizens should be granted exemptions when such exemptions do not offend basic justice (e.g. Nussbaum 2008). Citizens of each response, I suggest, can recognise the reasonableness of the other position: both are reasonable interpretations of what a commitment to the freedom and equality of citizens requires in this area. Contrast these with a third possible response: the state should grant exemptions to those from monotheistic traditions but not from polytheistic traditions. This response could not plausibly be seen as a sensible conclusion when reasoning about the demands of freedom and equality. Nor could a fourth response, contending that citizens who peacefully seek exemptions through law should be imprisoned for threatening public order. These latter two positions are outside the scope of reasonable disagreement on the matter. They are unreasonable positions to hold.

How are we to guarantee that citizens' lists of what qualifies as reasonable positions, and what qualifies as unreasonable positions, will be the same? We cannot: we can only argue about it, and hope that there is sufficient convergence to establish a basis of shared, public reasoning. Rawls presents three criteria for what qualifies a proposed conception of justice as a reasonable conception - that it provides basic liberties, that it establishes equality of opportunity, and that it guarantees the satisfaction of material basic needs. Rawls's hope is that citizens will concur with his criteria (Rawls 2005, p. 450). Such shared criteria are essential for any group of people to be described accurately as a political community (in Duff's terms), given the fact of reasonable disagreement. Indeed, that idea - that without a shared

finding a tax policy or a police policy, for such a move would entail abandoning what it is they are disagreeing about: the realisation of justice. They agree that some acceptable solution is required, even as they continue to disagree about what the best solution is. For a discussion of this "asymmetry objection" to political liberalism, see Quong 2011, pp. 192-220. 
sense of the kind of outcomes that are beyond the pale, morally, a political community does not obtain - is considerably at home in Duff's view:

[C]ommunities...have formal structures of authority and rules that should express the community's defining values and assist the pursuit of its distinctive goods. Their members must be able to see them as 'our' rules, and as rules that suitably order their academic activities. If they cannot accept the rules as embodying at least a reasonable conception of the community and its goods, they must see them as alien impositions, which they might have to obey but cannot accept as theirs (Duff 2001, p. 44, italics added).

What this picture establishes is that the procedure to be secured for the political community - to settle provisionally its reasonable disagreements about the implications of shared values - cannot be just any proposed procedure. Rather, it must be one - if one can be identified - that has a tendency to select solutions that are from the list of reasonable possibilities on any given matter. What might this be? The argument I find most plausible runs along the following lines: Given that it is part of the idea of liberal political community that citizens roughly share the right (i.e. liberal) values, then it is plausible to presume that, in a context with widespread attitudes of open-mindedness, critical scrutiny, and conscientious deliberation, there is a justifiable presumption that majoritarian voting procedures among adult citizens will have a tendency to be "epistemically superior" (i.e. superior at selecting reasonable candidate positions on policy matters) to any available alternative mechanism. I shall not defend this thesis here, as so doing would entangle me in considerable disputes in democratic theory.

An account of democracy of this partially epistemic variety - an account, that is, whose justification is sensitive to the substantive justice of democracy's outcomes - is one plausible way to understand how the members of Duff's political community might decide to settle provisionally their reasonable disagreements about justice. While it is possible that other decision procedures remedy the "decision deficit" exhibited by Duff's theory in plausible ways, some account of democracy that is grounded partly in citizens' mutual understanding of the acceptable scope of state action is a plausible alternative (Cf. David Estlund 2008).

However, note one feature of the kind of democratic view that I am proposing to saddle upon Duff's theory. If the aim of democracy is to select from among rival views about what it means to respect citizens as free and equal on a given policy matter - as I believe it is - then the value of democracy is not merely intrinsic (i.e. derived from the way it respects citizens' autonomy, regardless of its consequences). Citizens should only be prepared to endorse democracy so long as it tends to serve the instrumental role it is designed to serve: to facilitate some reasonable decision for the polity in the face 
of various reasonable proposals. When it serves this aim - when decisions are reasonable - the outcomes of democracy are viewed as legitimate, as representing the polity's shared (provisional) response to a policy question - something conceived as authorised by, and enforced in the name of, all citizens. Seeing the law as jointly authored in this way could only be compromised by legislation that undermines the standing of citizens as free and equal - that exists beyond the pale of reasonable disagreement.

\section{Distributive Injustice: A Case of Reasonable Disagreement?}

I have clarified the picture of political community in which the debate over punishment of socially deprived offenders is properly situated. With the framework established, I can ask: how should policies that lead to social deprivation be understood in the above scheme? Is the justice of such policies subject to reasonable disagreement - such that those who do regard them as injustices still see them as their law? Or is it, on the other hand, "beyond the pale" of reasonable disagreement - something that fundamentally imperils the standing of certain citizens as free and equal?

It is important to realise just how complicated this question is. Often the kind of social deprivation that exercises the concern of egalitarian liberals is generated by a complex policy regime - a vast array of statutes and national and local policies concerning taxation, welfare programmes, education, healthcare policy, gun policy, employment law, drug policy, and more. Much of the disagreement hinges on empirical controversies about the likely (combined) effects of different policies. With this in mind, the question is not: is there reasonable disagreement about the causes and remedies of the horrific circumstances that rattle so many urban populations? Rather, the question is: is there reasonable disagreement about whether these circumstances are evidence of injustice, and that some form of policy redress is necessary?

If the answer is yes - if citizens properly judge one another to be engaged in a sensible dispute about the limits of state power in deciding whether there is or is not a political responsibility, flowing from the commitment to others as free and equal, to do something about the current state of affairs - then this philosophical investigation can end. In such a state of affairs, those on the side of the reasonable disagreement who contend that an injustice is transpiring still properly view themselves as morally connected to their fellow citizens, judging them to have an inferior (though not unreasonable) position 
on the substantive justice of the matter. In such circumstances, they still see the law as theirs, even though they disagree with it.

But if the answer is no - if there is no plausible argument that could show how a pro-status quo attitude toward our urban ghettos is compatible with an enduring commitment to the status of all as free and equal - then we have a problem. The problem is that those citizens who, in such a case, correctly judge the policy regime as being "beyond the pale" suddenly have a shakier relation to their co-citizens, who (they properly judge) have supported an egregious injustice. How should such citizens understand themselves and their relation to the state in such a situation? And what does the answer to that question reveal about the state's standing to punish?

\section{Distributive Justice and the Right to Punish}

To answer these questions, let us return to the thesis that inaugurated the occasion for this exploration: Duff's claim that a society that perpetrates distributive injustice loses its standing to punish victims of the injustice. The argument, in its most recent form, proceeds via an analogy with blame. What makes it possible for someone to lose the standing to blame is if she has acted in a way that denies the fellowship upon which the legitimacy of blame is predicated (Duff 2010, 128). Because "[c]alling others to answer, must be a reciprocal activity" - an activity among "fellow members of an appropriate moral community" (Duff 2010, 126) - the lack of reciprocity undermines one's standing to call others to answer, including to blame. I cannot call you to answer for affronts to our shared values you have committed unless I am prepared for you to call me to answer for affronts to our shared values that $I$ have committed.

Now comes the analogy with matters of law and punishment. The state cannot hold socially deprived offenders accountable for flouting the community's values if it is not willing to let them hold it accountable for flouting the community's values. Yet by flouting the community's values as a matter of regular course - by enacting deeply unjust laws backed by coercive threats that have the effect of generating profound social deprivation - the state implicitly denies that such socially deprived citizens are actually full members of the moral community. In so denying their basic civic status, it forfeits its claim to hold them accountable when they act wrongly. The state's standing to punish has, in short, been compromised by its perpetration of grave injustice. 
Let us assume that Duff's basic idea - that it is possible to compromise one's standing to blame or punish others in virtue of how one has treated others - is correct. I shall not subject this claim to scrutiny here; others have done so extensively (Matravers 2006; Holroyd 2010). It is crucial to note, of course, that the argument works for Duff precisely because his view of punishment is the communicative one of calling to account; for views of punishment for which the aim of deterrence is the objective - the aim of keeping vulnerable people safe, regardless of how those who pose a danger have themselves been treated - his conclusion does not follow as straightforwardly.

With the broad outline of Duff's argument clear, consider the proposed modification to it by Peter Chau. Chau also accepts Duff's claim that it is possible for someone to compromise her right to blame or punish. His attack on Duff concerns the specific claim that the state has necessarily lost its right to punish owing to laws that are gravely unjust. While Chau accepts that those citizens who are causally responsible for the relevant unjust legislation have lost their standing to punish, he questions the thesis that a court issuing punishments must conceive itself as speaking in their name. Why can't the court conceive itself as speaking in the name of states who cannot be plausibly seen as causally responsible for the unjust legislation - those "righteous people who work for social justice and donate a large amount of their income to help the poor" (Chau 2012, p. 248)? On this view, "the courts can be seen as acting, not on behalf of the whole polity, but only on behalf of a subset of its citizens, namely, the just citizens (i.e. the citizens who cannot be seen to have wronged the deprived offenders)" (Chau 2012, p. 248).

With Duff's and Chau's arguments freshly articulated, we can now assess their dispute within the vision of liberal-democratic political community developed in the previous sections. How can the distinction between reasonable disagreements about justice, and unreasonable disagreements, illuminate their debate ${ }^{9}$ It is clear that Duff's argument - that the state loses its standing to punish - does not coherently apply in cases where the putative injustice is subject to reasonable disagreement. There is nothing, in such a state of affairs, unobjectionable about punishing citizens who commit crimes in these contexts, as there is reasonable disagreement about whether such offenders even qualify as victims of

9 That it is a debate is revealed by the various footnotes in Chau's work indicating Duff's suggested refutations of Chau's position. 
injustice in the first place. Importantly, this result would also imply that the offenders would have no grounds for, along the lines of Duff's argument, denying that the state has the standing to call them to account. Offenders could, of course, register their disagreement with those citizens who have supported the legislation in question, but as it would be reasonable disagreement, the basic structure of citizens' relations to one another - in light of the urban policy regime's democratic legitimacy - would remain intact.

Given that Duff's proposal could only potentially apply in cases of legislation whose injustice is "beyond the pale" of reasonable disagreement, Chau's suggested modification could only plausibly apply in such cases as well. This makes the use of the predicates "just" and "unjust" in Chau's analysis unfortunate; it is far better to refer to legislation that is legitimate or illegitimate. I may well believe that a top tax rate of $40 \%$ is unjust, contending that $35 \%$ is the most reasonable tax rate; but as it is subject to reasonable disagreement, I would not deny the authority of the state to enforce the $40 \%$ rate. This clarification means that the sort of laws that could ground the claim that the state lacks authority to punish must be of a particularly pernicious character.

So the debate between Duff and Chau must concern criminals who are victims of unjust legislation whose injustice is beyond the pale of reasonable disagreement. Because this debate only makes sense under such an assumption, I shall from now on assume that the policy regime they both have in mind is, in fact, beyond the pale of reasonable disagreement. It is worth adding, of course, that if Duff and Chau contend that certain forms of actually-existing distributive injustice are beyond the pale (as they must for their positions to be plausible), I believe they are correct to do so. Whether the policy regime that prevails in many of the West's urban ghettos is the result of injustice is not, to my mind, subject to reasonable disagreement; this is something that liberals of libertarian and egalitarian stripes must believe in order truly to be liberals. ${ }^{10}$ I shall not, however, defend that contention here.

So let it be assumed that the policy regime in question is beyond the pale. In our analysis of this legislation, there are four groups of people we can distinguish in preparation for evaluating Chau's

10 Why libertarians? Firstly, because even right-libertarians should be committed, as Nozick exhorts them in the final pages of Chapter 7 of Anarchy, State, and Utopia, to redistributive policies that rectify historical injustices (1974, p. 231). Secondly, most libertarians would object to the maddening range of disproportionate criminal penalties, especially for infractions such a drug possession or sale which libertarians judge not to be properly criminalised. 
proposal. Firstly, there are the supporters of the status quo - call them hardline co-opted ${ }^{11}$ libertarians - who believe there is obviously no injustice afoot in the urban ghetto, and indeed find those who think there is an injustice unreasonable in their beliefs. Secondly, there are supporters of the status quo - call them softline co-opted libertartians - who believe there is no injustice afoot, but see the logic of the arguments that imply there is; these people are unreasonable, as they still support the decidedly unjust policy regime, but they have the (mistaken but superior to the previous) position that the matter at hand is subject to reasonable disagreement. Thirdly, there are softline egalitarians, who (mistakenly) believe there is reasonable disagreement about their (correct) belief that there is an injustice in the urban ghetto. And fourthly, there are hardline egalitarians who (correctly) believe there can be no reasonable disagreement about their (correct) belief that there exists an egregiously unjust policy regime that afflicts the polity's urban ghettos.

The group that interests us is the fourth group: the people with the full knowledge, so to speak, of the moral facts. How should they understand their relation to the rest of the society? These people may well be citizens, or the public officials - like judges or prosecutors - who potentially have the power to let their moral convictions influence their decisions. How should they regard the state's decision to punish victims of injustice?

There is an intuitive inclination to think that such figures would object to punishing victims of injustice: the state has, after all, lost its standing. But Chau's claim is precisely that they can think of themselves as disassociated from their democratic co-citizens. Speaking on their behalf to socially deprived offenders, judges can say: Many of my fellow citizens have disgraced you, but the citizens I represent have not. We have supported you, and in return you have committed grave public wrongs. You have raped and assaulted and murdered innocents. Our compatriots may have lost standing to blame you for these horrific crimes - to hold you to account for how you have wronged some of our other fellow citizens - but we, the just citizens, have not.

Should the hardline egalitarians think and say such things? There is considerable moral pressure to think they should, since it would mean we would be morally justified by continuing to punish socially deprived offenders who commit crimes. And the reason we want to be able to continue punishing such

11 "Co-opted" because there is no plausible libertarian theory, on the right or left, that could justify their position. 
offenders is precisely to protect their prospective victims. To say that the state has lost its standing to punish socially deprived offenders, after all, appears to give up on the state's role in defending those who are at risk of being harmed by them. As Victor Tadros writes:

Failing to hold the poor responsible for the crimes that they commit may, however, constitute another kind of injustice. For one thing, we might fail to provide an adequate public response to a wrong that has been done to the victim, and the victim might have a special kind of interest in there being such a public response. Furthermore, failing to hold poor criminals responsible for their crimes might further erode the security of the poor. The poor, by being victims of distributive injustice, are already worse off than they ought to be in security terms. One reason for this is that wealth provides us with opportunities to make ourselves more secure (2009, p. 393).

One motivation for Chau's argument therefore may well be some moral impetus for the state to remain involved in protecting the prospective victims of socially deprived offenders, even as it continues its distributive injustice. And the way to justify that remaining involvement is to see the enforcement of punishment as disconnected from the perpetration of the injustice. ${ }^{12}$

Before proceeding, it should be clear that Chau's argument has a certain prima facie implausibility. That is because the state officials who are perpetrating the injustice may well be the very same people who are enforcing the punishment system. Are they to see themselves as representing the unjust citizens when they do the former, and the just citizens when they do the latter? This seems incoherent: if they were the kind of people who would be inspired by justice, why would they be serving a system that was perpetrating such grave injustice? There is something right about this objection, and something wrong. To understand what, however, I must first propose the analytical framework within which we can understand the cases in which Chau's proposal has limited applicability. Once that framework is clear, I shall return to this objection.

\section{From the eyes of the just alone? When normative community breaks down}

I now propose a rough framework to help make sense of this sort of situation - a situation in which some minority of just citizens and officials in a democracy are confronting a set of persistently unjust circumstances that they correctly judge to be beyond what any reasonable conception of justice would allow. I propose that situations of the kind are best conceived as episodes of democratic crisis:

\footnotetext{
${ }^{12}$ Note that it is difficult to motivate this aspiration - to punish offenders in order to keep vulnerable innocents safe - from within Duff's theory of punishment, which conceives punishment as a communicative endeavor oriented to moral restoration, rather than a deterrence-oriented system aimed at crime prevention. This reveals a lacuna with Duff's account that is best resolved by incorporating a concern with deterrence into his framework. I cannot undertake such an ambitious theoretical task here.
} 
circumstances in which the justifying preconditions of democracy fail fully to obtain. They fail to obtain because, as previously argued, democracy is justified with reference to the aspiration of provisionally settling reasonable disagreements by selecting some reasonable position on a policy matter for enactment. Moreover, the operationalisation of such an ideal presupposes the existence of consensus among citizens about what might be called the community's black list - the kinds of laws that, mostly everyone agrees, clearly run afoul of the community's standards. I argued before that when citizens' lists aren't the same, a moral community can no longer plausibly be said to obtain. In short: No moral community, no justified democracy. No justified democracy, no requirement that just citizens see themselves as associatively bound to those perpetrating evil around them.

This is the predicament that the hardline egalitarians find themselves in. Doubtless there is pressure for them to feel disassociated from their co-citizenry. But what I want to insist is that there is also pressure to feel continually bound by it, even as the state enacts grave injustices. To demonstrate this pressure, consider the following distinction between two forms of democratic crisis:

- Rectifiable disalignment. In this situation, citizens lack a shared sense of what are the reasonable candidate positions on an issue and what are not. However, the disagreement is contained to only a small number of issues of basic justice. There is broad agreement on much else. Moreover, there is potential, with a sufficient amount of time and deliberation, to bring the citizens who hold unreasonable beliefs on the relevant issue into the territory of the reasonable, even if barely. Given the fragility of institutions and the moral costs of undermining them, citizens who judge themselves to be in a state of rectifiable disalignment should continue to see themselves as democratically associated with their cocitizens. $^{13}$

- Stable fracture. In the event of a stable fracture, the normative community is split, and there is no evidence it will regain its coherence (if it even had it) anytime soon. In such circumstances, citizens and officials with reasonable convictions are justified in seeing themselves as democratically disassociated from their fellow citizens. That does not mean they should say so. In the event of stable

\footnotetext{
${ }^{13}$ One might think that the discussion of the moral permissibility of torture in the U.S. over the past decade reveals some rectifiable disalignment. The anti-torture forces had been convinced that torture was on liberal democracy's "black list" - that it was something it would never do, being beyond the pale. Nevertheless those who opposed torture did not proceed as though their political adversaries were beyond persuasion. They saw the disagreement, though unreasonable, as rectifiable. I thank Jeremy Waldron for this example.
} 
fracture, political strategy within moral limits becomes the guiding code. People should continue to explore possible ways to narrow differences, but they should attempt to increase the amount of justice incrementally through various activities. In the event of certain severe stable fractures, violence and political revolution can be justified. This is a case of modus vivendi politics par excellence (cf. Rawls 1994, p. 126).

I believe that citizens are subject to a normative requirement to presume that they reside in a state of rectifiable disalignment, rather than stable fracture, unless conclusive evidence to the contrary is adduced. Such evidence consists in the repeated attempts to rectify an injustice over generations. Doubtless some will claim that the distinction between temporary disalignment and permanent fracture is too nebulous to constitute a useful basis for political judgement. No doubt further distinctions could be made to allay this worry, though that task would be most fruitful as an historical one of looking at different injustices in particular contexts and asking what it would have been reasonable to believe about them at the time. ${ }^{14}$

It is crucial to remember the argument for the moral presumption in favour of disalignment in cases of unclarity. The costs of conceding publicly that a permanent fracture has transpired are incredibly high. There is considerable moral reason to work to hold the community together, even if it involves compromising (as politics inevitably does) on certain matters of important principle. Only if moral civil war has gripped the polity should judgements of permanent fracture be rendered. After all, once citizens and officials conduct their political relations from the assumption that they are in a state of stable fracture, rather than rectifiable disalignment, they further unravel the democratic ties that are indispensable to the enduring achievement and maintenance of just institutions. ${ }^{15}$

This distinction helps us better to think about, and respond to, Chau's proposal. It also helps us respond to his refutations of possible objections to his proposal. He refers to what he calls the authorisation objection, which stems from the claim that just citizens have not authorised the courts to act in their name. His proposed reply to his objection is as follows:

\footnotetext{
${ }^{15}$ It is, of course, logically possible for a co-citizenry to rest in major agreement on all major questions of policy except one, on which they intractably and irreconcilably disagree. Consider, after all, the case of abortion. Does a moral community exist in such a case? It is difficult to say. Provided both sides are committed to the position that dispute over the one issue will not destroy the rest of their politics, a plausible the answer is "yes".
} 
My first reply to the authorisation objection is that if authorisation is the problem, then the problem can easily be solved by asking the just citizens to authorise the courts. The standing of the courts can then be recovered over night, if just citizens do whatever is required (e.g., submitting letters) to authorize them. Duff's argument then fails to show that just punishment of deprived offenders in an unjust society is impossible, as radical restructuring of the society towards social justice in the ways that Duff envisaged is unnecessary for the courts to recover their right to blame (Chau 2012, p. 250).

This reply, however, is deeply inadequate. First of all, it is highly unclear who is "asking" the just citizens to mail letters to courts authorising them to punish the victims of laws the just citizens have themselves opposed. Secondly, even if the distributive justice-minded citizens were suddenly to grow anxious about courts not punishing criminal offenders who had been victims of distributive justice, the just citizens may not be morally permitted to authorise courts in the relevant way. For, under conditions of temporary disalignment, they ought still to view the law as democratically authorised - something that is enforced in their name. And in conditions of permanent fracture, rogue officials would have no need for authorisation; working within an unjust regime, they would be morally permitted to take the necessary steps to increase the amount of substantive justice through the means available.

\section{From Theory to Practice}

These conclusions might seem paradoxical. How odd, we might think, that victims of distributive injustice who contravene just legislation could legitimately be punished in a society with a stable fracture among citizens about what justice requires, yet not in a society with (what is reasonably judged to $\mathrm{be}^{16}$ ) a temporary fracture. The oddness traces, I think, to the character of the situation when viewed from the perspective of potential offenders. Especially if "rogue" officials are keeping a secret their judgement that their society has gone off the moral cliff, so to speak, are offenders simply to hope that their punishment is, in fact, the legitimate work of secretive justice-advocates high above, rather than the illegitimate work of officials who continue to speak in the name of an entire citizenry properly seen as complicit in injustice against them? However, I propose that the oddity vanishes when we see what else would be true of the contexts in question. Here, two claims become relevant.

Firstly, take the context in which the egregious injustice represents a rectifiable disalignment. In such a case, as I have argued, there is no public official who ought to view herself as in a state of rift from her co-citizens; she ought to conceive the moral community as intact, albeit precariously. She therefore cannot see any punishments she metes as something she does on behalf of only a subset of the

16 This phrase is more crucial than many philosophers - I suspect including Chau - would concede. The point of political and moral philosophy is not to identify the principles that enable God to track rightful and wrongful actions from the cosmos, but rather to identify principles that can enduringly regulate our own actual human practices. 
citizenry. Does this mean, therefore, that she lacks standing to punish? The immediate answer, on Duff's view, is yes, owing to the fact that the political community "displays no awareness of its failure to treat [the offender] as a citizen" it its administration of distributive justice, yet suddenly does when she commits a crime (Duff 2001, p. 199). However, as does goes on to say-and here it is worth quoting fully:

Suppose that there is, through the community's institutions and its government, a collective recognition of the wrongs she (and others similarly placed) have suffered, and a collective commitment to correcting them. That correction will be a large and lengthy task that might take decades to complete; and until it is at least well advanced, the community's right to call those who have suffered such exclusion to answer for their crimes is still undermined. But it is not as radically undermined as it was before: for the very fact of this collective recognition, this collective commitment to correcting the wrongs, displays a recognition of and concern for those who have suffered those wrongs as fellow citizens - as members of the community who share in its goods. Since to call them to answer for their crimes is also, so long as that calling to answer itself constitutes a communicative enterprise of the appropriate kind, to treat them as citizens, perhaps it can be (imperfectly) justified as a part of that very commitment to include them as fully recognize members of the polity (Duff 2001, p. 199).

In the context of temporary disalignment, a morally motivated official - the kind of official to whom we are speaking when we develop action-guiding moral principles for her consideration and endorsement - ought to pursue the task of restoring justice: of persuading her colleagues and the public that they have been deeply mistaken in their convictions about distributive, criminal, and drug policy, resulting in serious wrongdoing against many citizens. And with such a campaign of persuasion underway by a committed cadre of moralists in office, there is some hope toward achieving the kind of "imperfect justification" that Duff intimates. If so, this assuages the oddity involved in thinking that a context of temporary disalignment would not allow any justified punishment of criminal offenders who were themselves victims of social injustice - which would objectionably leave their prospective victims wholly without security. And, of course, if no officials are properly morally motivated, temporary disalignment was probably the wrong diagnosis in the first place.

This enables us to understand more completely an objection to Chau's proposal considered earlier. Recall the thought that Chau's proposal is prima facie incoherent: it requires the same officials to view themselves as acting in the name of the unjust citizens when enforcing distributive injustice, but in the name of just citizens when enforcing punishment against socially deprived offenders. In states of temporary disalignment, this state of affairs would not obtain, as officials could see themselves democratically bound to their co-citizens, despite the latter's support for deep injustice, and the conceptualisation urged in the previous paragraph would apply. 
But what if the efforts of just officials and citizens to persuade recurrently failed? What if, despite all the efforts morality could reasonably require of them, pervasive injustices remained? In such circumstances, judgements of stable fracture would be appropriate. And because an (accurately) morally minded judge would (in such tragic circumstances) be democratically disassociated from her fellow citizens, she would lack the pro tanto reason not to punish that she would retain in circumstances of temporary disalignment; she would, in other words, retain the right to call to account those who contravene legitimate liberal criminal laws. Would the offenders to whom she handed sentences know that she had the standing to punish them? It would depend, I think, on whether it would be of greater or less moral productivity for her to be public about her convictions. It is certainly possible that offenders would be in the dark about the justifiability of their own punishment, a prospect that appears disconcerting. But its disconcerting character traces to the moral pandemonium of the whole situation - and while we should be disconcerted, those who are just should not react by turning dangerous people loose on the rest of the population that has been failed by their government. For, by seeking justice in a tragic world, we retain the standing to hold others accountable for their evil.

\section{Conclusion}

I have argued that only in the most tragic of circumstances, in which the bonds of moral community have been broken beyond conceivable repair, do political officials have moral reason to see themselves as speaking only in the name of some. In those dire circumstances, such officials and the just citizens for whom they speak have reason to support punishments of socially deprived citizens who violate legitimate liberal criminal laws such as prohibitions on murder, assault, and rape. They retain the standing to call others to account. But even justice-seeking officials in less dire circumstances retain such standing. For while they remain democratically bound to their co-citizens - implying that they are connected to a body of people who have lost their standing to punish - such standing can be regained through the conscientious search for moral improvement. By acting as moral leaders in such episodes of rectifiable disalignment, they can restore moral community - and with it, an uncompromised authority to punish those who violate the rights of others.

John Rawls explains compellingly what a moral community predicated on a shared commitment to freedom and equality would be like: a society in which citizens exchange arguments that they reasonably could expect others to accept (1994). Since Rawls, prominent defenders of freedom and 
equality have filled in the picture of what a society of people united in their basic values would be like. Some theorists, like G.A. Cohen, have extended Rawls's theory to explain how it applies in surprising ways to the ethics of everyday citizenship (2008). Other theorists, like Jeremy Waldron, Joshua Cohen, and David Estlund, have extended our vision of liberal-democratic order to understand how the vision of a society united around shared values becomes much more nuanced - and more procedural - when we take seriously the fact of reasonable disagreement about justice $(1999 ; 2009 ; 2007)$.

All of these theories, however, have been conducted within the presumption that people generally share the same basic convictions about what justice requires - that they, in the language I've proposed, share the same "black lists" of morally unthinkable laws. But the persistent injustices we see throughout the West command attention to a different sort of politics: one in which our black lists are only partially overlapping. Perhaps on such "classical" shared concerns of liberals, such as freedom of speech and association, an overlapping consensus still obtains. But on matters of economic distribution - on matters concerning whether the public is responsible for ensuring the conditions of basic material security and dignity - we find ourselves not in a politics of the overlapping, but in a politics of the conflicting. We find ourselves, with respect to many issues of major and enduring concern, in a modus vivendi with people whose views on matters of grave importance are profoundly unreasonable.

Citizens need to know what political morality requires of them in these contexts, which our own societies too often resemble. They need frameworks to help them judge what to do. Far too much philosophy is done on how citizens think about one another in contexts where - by the magical wave of the philosopher's idealising wand - citizens share the same lists of what is reasonable and what is not. We need to start doing political and legal philosophy for societies in which citizens do not have the same list. How such citizens ought to understand the character of their political relations remains, at the level of theory, profoundly unclear. Given the willingness of societies to punish, the stakes could not be higher.

\section{Bibliography}

Anderson, E. (1999). Code of the Street: Decency, Violence, and the Moral Life of the Inner City. New York: W. W. Norton \& Company.

Barry, B. (2001). Culture and equality. Oxford: Polity Press. 
Butler, B. (2004). “A Hip-Hop Theory of Punishment.” Stanford Law Review 56: 988.

Chau, P. (2012). "Duff on the legitimacy of punishment of socially deprived offenders," Criminal Law and Philosophy 6(2), 247-254.

Cohen, G.A. (2008). Rescuing justice and equality. Cambridge: Harvard University Press.

Cohen, J. (2009). Philosophy, Politics, Democracy. Cambridge: Harvard Universitry Press.

Duff, R. A. (1986). Trials and punishments. Cambridge: Cambridge University Press.

Duff, R. A. (1998). Principle and contradiction in the criminal law. In R. A. Duff (Ed.), Philosophy and the criminal law (pp. 156-204). Cambridge: Cambridge University Press.

Duff, R. A. (2000). "Whose Law is it anyway? Inclusion, exclusion and the criminal law." Scottish Affairs, 30, 2-15.

Duff, R. A. (2001). Punishment, communication, and community. Oxford: Oxford University Press.

Duff, R. A. (2007). Answering for crimes. Oxford: Hart Publishing.

Duff, R. A. (2010). "Blame, moral standing, and the legitimacy of the criminal trial." Ratio, 23(2), 123-140.

Estlund, D. (2007). Democratic authority. Princeton: Princeton University Press.

Holroyd, J. (2010). "Punishment and justice.” Social Theory and Practice, 36(1), 78-111.

Matravers, M. (2006). "Who's still standing: a comment on Antony Duff's preconditions of criminal liability." Journal of Moral Philosophy, 3(3), 320-330.

Miron, J. (2001). "Violence, Guns, and Drugs: A Cross-Country Analysis." Journal of Law \& Economics, 44 (2), 615-633.

Nozick, R. (1974). Anarchy, State and Utopia. Malden: Basic Books.

Nussbaum, M. (2008). Liberty of Conscience. New York: Basic Books.

Quong, J. (2011). Liberalism without Perfection. Oxford: Oxford University Press.

Rawls, J. (2005). Political Liberalism. New York: Columbia University Press.

Simon, D. and Burns, E. The Corner (Edinburgh: Canongate, 2009), 66.

Tadros, V. (2009). "Poverty and Criminal Responsibility.” Journal of value inquiry, 43, 391-413

Waldron, J. (1999). Law and Disagreement. Oxford: Oxford University Press. 
Warr, M. (2002). Companions in Crime: The Social Aspects of Criminal Conduct. Cambridge: Cambridge University Press.

Weithman, P. Why Political Liberalism? On John Rawls's Political Turn. New York: Oxford University Press.

Wilson, W.J. (1987). The Truly Disadvantaged: The Inner City, the Underclass, and Public Policy. Chicago: University of Chicago Press. 